\title{
Reproductive Rights and Reproductive Choice of Yoruba Women in Southwestern Nigeria
}

\author{
Yusuff Olabisi Sherifat \\ Department of Sociology, Faculty of Social Sciences, Lagos State University \\ * Corresponding author email: soyusuf@yahoo.co.uk
}

Received: 19 November 2019 / Revised: 22 December 2019 / Accepted: 28 December 2019 / Published: 31 December 2019

\begin{abstract}
While some social and health comes have improved significantly for women, significant gaps remain in the achievement of reproductive health rights and women's choice. Women are still constrained by social, legal, religious and cultural impediments and family power dynamics from acting on their desires. The objective of this paper therefore is to examine the reproductive rights and choice of women entrepreneurs in South Western Nigeria Ibadan. The study adopts Rational Choice Theory and Gender role theory as theoretical guide. Quantitative and qualitative methods of data generation were employed. One Hundred and Twenty questionnaires were distributed to women with ten years marital experiences. The distribution of hundred and twenty questionnaires to women respondents was obtained through snowball method. Only In-depth interview conducted among 24women through purposive sampling techniques was employed to generate qualitative data. Quantitative information was analysed through simple percentage and frequency distribution. Findings from the study revealed that women's reproductive decision-making processes are greatly influenced by their partners ranging from their age at first marriage, their access to family planning and abortion., which also given by the women as challenges on their reproductive rights in Sango, Ibadan.
\end{abstract}

Keywords: Reproductive Health, Reproductive Choice, Women, Yoruba, South-Western Nigeria

\section{Introduction}

Reproductive Rights (RR) are integral to the full realization of Reproductive Health (RH) (Tahzib F, 2012). It is quite disheartening that after thirty years of Beijing Conference in China, women in developing countries are still not in control of their sexual and reproductive health rights (Ifemeje, Obidinma and Umejiaku (2013).Malhotra, McGonagle and McCleary(2012) argued that women are still constrained by myriads of barriers to autonomously define and achieve their reproductive intention. Women reproductive constraints are influenced by gendered roles and relationships which have enormous direct and indirect consequences for women's health, wellbeing and life options. They also hinder the achievement of broader development goals, including gender equality, economic opportunity, fertility reduction, and social inclusion (ICRW, 2012). In the year 2014, the World Health Organization (WHO) showed that despite the progress made, societies are still failing women in relation to health, most especially in poor countries and among the poorest women in all countries. The poor sexual and reproductive health outcomes represent one third of the total global burden of diseases for women between the ages of 15yrs and 44yrs.High maternal death are still recorded. Reproductive rights $(\mathrm{RR})$ and reproductive health $(\mathrm{RH})$ therefore continue to be topical in developing countries because of the heavy death toll attendant at child birth (WHO, 2007).

It is important to note that in a patriarchal Nigeria society, rights to decide on the numbers of children between couples is more relied on men's authority despite the fact that a woman's fertility more often depend on women's body (Center for Reproductive Law and Policy (CRHP, 2008(Isiaka and Yusuff, 2012),).This is a serious constraints to women attaining reproductive health rights. With globalization, and women having access to formal education, there is likelihood of people's perception changing towards reproductive health decision making, thus giving women more rights to decide on their sexual and

Copyright (C) 2019. The Author(s). Published by AIJR Publisher.

This is an open access article under Creative Commons Attribution-NonCommercial 4.0 International (CC BY-NC 4.0) license, which permits any non-commercial use, distribution, adaptation, and reproduction in any medium, as long as the original work is properly cited. 
Reproductive Rights and Reproductive Choice of Yoruba Women in Southwestern Nigeria

reproductive health rights. Reproductive choice is a very important element of reproductive health which also constitutes a number of basic facets. Such facets include women's ability to regulate their fertility, ability to reproduce, and that women are able to go safely through pregnancy and childbirth, and that reproduction is carried to a successful outcome through infant and child survival and well-being (Aniekwu 2012).

The right to reproductive choice means that women have a right to choose whether or not to reproduce, including the right to choose whether to carry or terminate an unwanted pregnancy and the right to choose their preferred method of family planning. Women's choice on reproductive health rights in this study therefore concerns with health issues of women in relations to abortion, family planning, the use of contraception and challenges on these reproductive choices. Thus, this study is aimed at examining the reproductive right and women's reproductive choice in Ibadan. There has been awareness on the right of women to reproductive health. This awareness has brought about an improvement in the experience of women's handling an unwanted pregnancy. In Nigeria, the penal and criminal laws prohibit abortion except when it is done to save the life of the expectant mother (Aniekwu, 2012). As a result of the country's restrictive laws, women undergo unsafe abortions at the hands of quacks and unqualified medical personnel and face threats to their physical, social and mental health. In Nigeria, between 10 and $50 \%$ of women who undergo unsafe abortions require post-abortion medical attention due to complications arising from the procedure. Such complications are due to infection, incomplete abortion, haemorrhage and injury to internal organs (WHO, 2004).

Historically, men have exercised enormous power over women's bodies through controlling their sexuality and reproduction. There had been several scholars' research and writings on women reproductive health. Among such are a critique of incessant violations of women's health and reproductive rights in Nigeria (Ifemeje et al, 2013), Sexual health and sexual rights within marriage(Aina, Aranisola and Osezua, 2006),gender empowerment and reproductive health, providing an explanation on getting the voice of women heard in the decision making process of family size (Corroon, Speizeir,Fotso, Akiode, Saad, Calhoun and Iran 2014). Other studies on reproductive health includes; the impact of Medicaid funding restrictions on woman's reproductive decision (2016) Also, a study of reproductive health and behaviour of women reflects the circumstances of the women's actions on their reproductive choice (2016). Despite the array of research on women's reproductive health, a very dearth study exists on the choices on women's reproductive health in Nigeria.

Reproductive rights are human rights in relation to sexual reproduction (Alubo, 2000). These rights are already recognized in national laws, international human rights instruments, and other consensus documents. The first comprehensive statement on human right was released in 1948 by the United Nations, but the statement lacked the pronunciation of right on reproductive health until twenty (20) years later in 1968 when the statement included that parents have the right to decide responsibly and freely on the number and spacing of their children, also the right to adequate education and information (United Nations, 1968; Lynn P. Freedman and Stephen L. Isaac, 2013).

The emanation of reproductive right of women therefore brought about the issue of reproductive choice because reproductive choice is all about having right and ability to choose from available alternatives pertaining to reproductive health (Anna-Britt Co, 2012). Freedman et.al (2013) argues that reproductive choice is women's right to reproductive life, an access to knowledge and information for various choices. The word "Choice" means one of a number of things from which only one can be chosen. Choice on individual reproductive decision-making is something particular and special having to do with the matter of who can make a decision of autonomy (Feredi, 2007). According to Feredi, reproductive choice is private matters that are resolved for one, it is more than health, and extends beyond equality and justice

In a nutshell, reproductive health therefore implies that people are able to have a satisfying and safe sex life and that they have the capability to reproduce and the freedom to decide if, when and how often to do so. It is the right of men and women to be informed and to have access to safe, effective, affordable and acceptable methods of family planning of their choice, as well as other methods of their choice for regulation of fertility, which are not against the law and the right of access to appropriate health care services 
that will enable women to go safely through pregnancy and childbirth and provide couples with the best chance of having a healthy infant (AniekwuNkoli, 2003). It is deduced from the above literatures therefore that reproductive choice is the ability to get informed and choose from the available reproductive rights and health

D' Souza (2016) examine the quality of life among Indian women, D'Souza et.al discovered that the physiological ability of women in India weakens as their fertility increase. For instance, women are not sensitized on the implication of large number of children on their physiological nature and their living conditions; it therefore mars the reproductive health of India women in Mining communities. Thus, even without the sensitization on the negative large number of children, the economic situation of the society can influence the structure the birth patterns in the society. The major public health and social problem all over the world is teenage pregnancy, and it is on the increase (Boyd 2000, Aboyeji 1997). The foremost consequence of the aftermath of unmarried adolescence pregnancy is that of its contributions to higher infant mortality (Becker, 2009), and its substantial contributions to the overall in Sub-Saharan Regions of Africa being regions with the highest level of early child bearing in the world (Sunday A. A., Araoye M. O., Akande T. M., Omotosho I. M., Monehin J. O., and Babatunde O. A., 2011). Reproductive choice may be impeded for a number of reasons. Lack of information, poverty, insufficient supply of essential materials and healthcare workers are obvious impediment to reproductive choice on reproductive health. Also, cultural and religious beliefs may influence the people seeking for reproductive health (Lucinda Vandervort, 2006)

Omolase, Faturotiand Omolase(2013) study, the findings showed that one out of five women reported having experienced an unwanted conception, and of these $5 \%$ had an abortion and an additional 9\% attempted unsuccessfully to end the pregnancy. This shows that Nigerian women are increasing in knowledge to prevent unwanted pregnancy. It is estimated that $25 \%$ of women who have had an abortion in Nigeria experience serious complications. Omolase et al (2013) revealed that for a more improvement against unwanted pregnancy, women must be aware of the methods available, must know where supplies of these methods can be obtained, and they must know how to use the method they choose. Due to lack of adequate information on the appropriate methods to reduce unwanted pregnancy, each year an estimated 500,000 women die of complications due to pregnancy, child bearing or unsafe abortion (Bankole, 2006) Information on the use of contraceptive methods is usually based on the prevalent method, and not on the perception of the policy makers. For instance, Rogers and Kincaid (2004); Valente, (2005) found that people chose contraceptive methods that are commonly used in their community because they know that it is socially acceptable to do so, and they tend to know more about these methods. Many women use the same family planning methods that others in their social network use (Godley, 2001). A 1998 study in urban Nigeria found that the most widely used method was the one that was popular in other cities and villages (Entwisle et al., 1999). The entire community may be encouraged to one type of contraceptive based on the choices of early contraceptive users, rather than individual needs (Potter, 1999).

It is pertinent to note that individual "choice" in reproductive decision-making is something special and particular. It relates to the matter of who can make a decision, which refers to the agency and autonomy of individuals. When we talk about reproductive choices, we refer to the private matters that each of us must be able to resolve for ourselves. This is more than health, and extends even beyond equality and justice (Feredi, 2007) Thus; this research study aims at examining reproductive rights and women's reproductive choice in Ibadan. The pertinent questions in this study include: What are the determining factors of women's right to reproductive health choices and decision making? What are the challenges of women's right to women's choice in reproductive life? The general objective of this study is to examine the reproductive rights and women's choice among Yoruba Ethnic group in South Western Nigeria

\section{Theoretical Orientation}

The fact that people act rationally has, of course, been recognised by many sociologists, but they have seen rational actions alongside other forms of action, seeing human action as involving both rational and non- 
rational elements. Such views of action recognise traditional or habitual action, emotional or affectual action, and various forms of value-oriented action alongside the purely rational types of action. Max Weber (1920), for example, built an influential typology of action around just such concepts.

In rational choice theories, individuals are seen as motivated by the wants or goals that express their 'preferences'. They act within specific, given constraints and on the basis of the information that they have about the conditions under which they are acting. At its simplest, the relationship between preferences and constraints can be seen in the purely technical terms of the relationship of a means to an end. As it is not possible for individuals to achieve all of the various things that they want, they must also make choices in relation to both their goals and the means for attaining these goals. Rational choice theories hold that individuals must anticipate the outcomes of alternative courses of action and calculate that which will be best for them. Rational individuals choose the alternative that is likely to give them the greatest satisfaction (Heath 1976: 3; Carling 1992: 27; Coleman 1973).

With reference to Jonathan Turner (1991), the basic assumptions of rational choice theory are; humans are purposive and goal oriented; humans make rational calculations in choosing lines of behaviour; humans have sets of hierarchically ordered preferences or utilities; emergent social phenomena are ultimately the result of rational choices made by utility maximizing individuals; finally, emergent social phenomena that are from rational choices constitute a set of parameters for subsequent rational choices of individuals. It is expected to retrieve from the respondents, how they make rational calculation on their reproductive decision-making process, how they also make list of choices where they eventually decide from, also to retrieve from them the causes of and reasons behind their action of reproductive decision making.

\section{Methodology}

The study population of this study are women with marital experience of 10years and above. The reason for this choice is that responses of the women with more marital experience may have more to say based on their reproductive rights and choice compare to others with lower experiences. The study area for the research was in Ibadan, Oyo State- South west, Nigeria. Sango area of Ibadan is reputed to be the largest indigenous city in Africa, South of the Sahara, and second largest city in Nigeria (Olatunji, 2012). The principal inhabitants of the city are the Yoruba; thus, culture and tradition is highly respected, and it is expected that women are subjected to men's order that they are not acting in superiority over men in any association and gathering (Olatunji, 2012). Ibadan, being an area embodied with various educational advancements ranging from the first University in Nigeria; the first teaching hospital in Nigeria; University College Hospital, and internationally acclaimed Institute of tropical Agriculture (ITTA), is worth measuring reproductive rights and women's choice in such an area as it will reveal how women's decision is given priority when it comes to reproductive choice.

A total of thirty (30) in-depth interviews were conducted among women of reproductive age group in Sango area of Ibadan. They were interviewed to share their experiences on their reproductive health, rights, the choice of reproduction, and the challenges of their respective choice. Their responses were tape-recorded when their consent was given. The respondents were purposively chosen, and questionnaires was administered to a total of One hundred and twenty (150) women within the reproductive age. The main purpose of administering questionnaires was to gather basic information that provides more general pictures of the characteristics. The questionnaire is semi-structured encompassing both opened and closed ended questions. The data analysis was based on 108 respondents out of 150 women of reproductive age that were administered questionnaires to. Thus, approximately $90 \%$ success rate was achieved on the respondents interviewed. 30 respondents were interviewed. In totality, information was collected from 138 respondents, and below are the frequencies and percentage of respondents' responses.

\section{Data Presentation on Socio-Economic Characteristics}

Table 1 shows that there is a majority of the respondents fall within the age under the ages 30-44years, representing 56 (48.4\%) of all the 138 respondents. This is line with the reproductive age bracket of women 
Yusuff Olabisi Sherifat, Adv. J Social Sci.; Vol. 6 Issue 1, pp: 138-151, 2020

as declared (UN women, 2016) on ethnicity, majority of the respondents were from Yoruba ethnic having constituted $65.9 \%$ (87). This is not surprising as Sango, the study area is Yoruba indigenous area. The table 1 also revealed that $1.5 \%$ (2) of the respondents contacted were practicing African Traditional Religion (ATR), 43\% representing 58 respondents were practicing Christianity religion, finally 72 of the respondents representing $54.6 \%$ of the respondents interviewed. There are $74.2 \%$ married respondents. This shows that majority of the respondents were in position to provide good and qualitative responses to the issue under study. On the level of education of the respondents, $96.2 \%$ of the respondents have at least attended primary school, which indicates that virtually all the respondents are literates. This shows that women have access and continue to have access to educational institutions. One major functions of education is awareness.

Table 1: Socio-Demographic Characteristics

\begin{tabular}{|c|c|c|}
\hline VARIABLES & FREQUENCIES (132) & PERCENTAGES (100) \\
\hline \multicolumn{3}{|l|}{ AGE BRACKET } \\
\hline $20-24$ & 11 & 7.6. \\
\hline $25-29$ & 17 & 12.9 \\
\hline $30-34$ & 30 & 22.7 \\
\hline $35-39$ & 16 & 12.1 \\
\hline $40-44$ & 18 & 13.6 \\
\hline $45-49$ & 24 & 18.1 \\
\hline \multicolumn{2}{|l|}{ ETHNICITY } & 12.9 \\
\hline Fulani & 3 & 2.3 \\
\hline Igbo & 17 & 12.9 \\
\hline Hausa & 19 & 14.4 \\
\hline Yoruba & 87 & 65.9 \\
\hline Edo & 6 & 4.5 \\
\hline \multicolumn{3}{|l|}{ RELIGION } \\
\hline African Traditional Religion & 2 & 1.5 \\
\hline Christianity & 58 & 43.9 \\
\hline Islam & 72 & 54.6 \\
\hline MARITAL STATUS & & \\
\hline Married & 98 & 74.2 \\
\hline Divorced & 4 & 3.0 \\
\hline Separated & 4 & 3.0 \\
\hline Widowed & 21 & 16.0 \\
\hline Cohabiting & 5 & 3.8 \\
\hline \multicolumn{3}{|l|}{$\begin{array}{l}\text { HIGHEST LEVEL OF } \\
\text { EDUCATION }\end{array}$} \\
\hline No education & 5 & 3.8 \\
\hline Primary certificate & 24 & 18.1 \\
\hline Junior Secondary Certificate & 16 & 12.1 \\
\hline Senior Secondary Certificate & 54 & 41.0 \\
\hline OND & 19 & 14.4 \\
\hline HND/University Degree & 14 & 10.6 \\
\hline
\end{tabular}


Reproductive Rights and Reproductive Choice of Yoruba Women in Southwestern Nigeria

Table 2: Family Planning and Reproductive Choice

\begin{tabular}{|c|c|c|}
\hline VARIABLES & FREQUENCIES (132) & PERCENTAGES (100) \\
\hline \multicolumn{3}{|l|}{ HAVE YOU GIVEN BIRTH? } \\
\hline Yes & 117 & 88.6 \\
\hline No & 15 & 11.4 \\
\hline \multicolumn{3}{|l|}{$\begin{array}{l}\text { HAVE YOU HEARD ABOUT FAMILY } \\
\text { PLANNING? }\end{array}$} \\
\hline YES & 132 & 100 \\
\hline \multicolumn{3}{|l|}{$\begin{array}{l}\text { WHAT TYPE OF FAMILY PLANNING } \\
\text { METHODS DO YOU ADOPT? }\end{array}$} \\
\hline Condoms & 12 & 9.1 \\
\hline Pills & 83 & 62.9 \\
\hline Coil & 43 & 32.6 \\
\hline Pregnancy Termination & 5 & 3.8 \\
\hline Injection & 95 & 72 \\
\hline $\begin{array}{l}\text { Abstinence } \\
\text { HOW DO YOU ACCESS THE FAMILY } \\
\text { PLANNING? }\end{array}$ & 7 & 5.3 \\
\hline Hospital & 64 & 48.5 \\
\hline Chemist & 25 & 18.9 \\
\hline Nurse & 22 & 16.7 \\
\hline Self & 21 & 15.9 \\
\hline \multicolumn{3}{|l|}{$\begin{array}{l}\text { WHAT ARE THE BENEFITS OF } \\
\text { FAMILY PLANNING YOU KNOW? }\end{array}$} \\
\hline $\begin{array}{l}\text { It makes one get more prepared financially for } \\
\text { pregnancy }\end{array}$ & 26 & 19.7 \\
\hline $\begin{array}{l}\text { It makes one focus on career without fear of } \\
\text { pregnancy }\end{array}$ & 35 & 26.5 \\
\hline It makes one space her children & 76 & 57.6 \\
\hline \multicolumn{3}{|l|}{$\begin{array}{l}\text { WHAT FACTORS DETERMINES THE } \\
\text { FAMILY PLANNING TECHNIQUE } \\
\text { YOU ADOPT? TICK MORE THAN ONE } \\
\text { IF POSSIBLE }\end{array}$} \\
\hline Cost & 32 & 24.2 \\
\hline Gender roles & 22 & 16.7 \\
\hline Community norms & 27 & 20.5 \\
\hline Health risk & 18 & 13.6 \\
\hline Religion & 26 & 19.7 \\
\hline \multicolumn{3}{|l|}{$\begin{array}{c}\text { WHO DETERMINES YOUR CHOICE } \\
\text { OF FAMILY PLANNING? }\end{array}$} \\
\hline Myself & 26 & 19.7 \\
\hline My spouse/fiancé & 106 & 80.3 \\
\hline
\end{tabular}

The responses in Table 2 reveal the choice of Ibadan women on family planning, question of whether the respondents have ever given birth, $94.7 \%$ of the respondents responded that they have given birth, either dead or alive, while $5.3 \%$ of them answered "NO". Thus, majority of the respondents have ever given birth. Of all the respondents interviewed or to which questionnaires were administered, none of them have responded that they have not heard about family planning before. This indicates that all the respondents contacted have heard about family planning. 
On the type of family planning methods, the respondents are familiar with, though there are opportunities for the respondents to identify more than one. Thus, majority of them indicated that they are familiar with the use of injection as a family planning method. However, $19.7 \%$ of the respondents are familiar pregnancy termination as method of family planning, $11.4 \%$ of them are familiar with abstinence, $44.7 \%$ of these respondents are familiar with Condoms as a family planning method, $73.5 \%$ of these respondents are familiar with injection, $91.7 \%$ of them are familiar with Pills, while $38.6 \%$ of these respondents are familiar with Coil method, making it the major method of family planning methods with which the respondents are familiar.

Having asked and documented the various methods of family planning the respondents are familiar with, there was also opportunities for the respondents to identify more than one method if possible, $9.1 \%$ of these respondents use Condoms as a family planning method, $62.9 \%$ of them use Pills, $32.6 \%$ of them use Coil method, 3.8\% of the respondents go for pregnancy termination as method of family planning, and $5.3 \%$ of them are using abstinence while $72 \%$ of these respondents are using injection, making it the major method adopting by the respondents as family planning method.

Majority of the respondents who use one method of family planning of another specified that they get access to these methods through professionals in hospital. Numerically, $18.9 \%$ of the respondents are having access to family planning through a Chemist, $16.7 \%$ of them get access to it through Nurse, while $15.9 \%$ of the respondents get access to family planning through a self-medication technique. On the benefits of family planning, to the people of Sango, Ibadan, $19.7 \%$ of the respondents contacted said that family planning makes them get more prepared financially for pregnancy; family planning allows $26.5 \%$ of the respondents focus on their career without fear of pregnancy, $57.6 \%$ of the respondents revealed that family planning allows them to space their children as they ever wish. Child spacing is highly or majorly considered as the benefits of family planning methods, according to these respondents.

Responding to their awareness on side effects of family planning methods, $73 \%$ of the respondents specified that they are aware of the side effects of family planning while $44.7 \%$ of them indicated that there is no side effect of family planning. This showed that majority of the respondents are aware of the side effects of family planning. Identifying the side effects of family planning, having mentioned that they are aware of the side effects, $17.4 \%$ of the respondents identified dizziness as side effects of family planning, $27.3 \%$ of them mentioned headache, and $31.8 \%$ of them mentioned complications, while $16.7 \%$ of these respondents identify the side effect of family planning to be loss or gain of weight. These responses shown that majority of the respondents identify that the major side effects of family planning is complications.

On the factors that determine the family planning methods the respondents adopt, having given the them liberty to choose more than one factors, $24.2 \%$ of the respondents said cost of the method determine the methods they adopt, gender roles determines the methods for $17.7 \%$ of the respondents, the determinants factor is community norms to $20.5 \%$ of the respondents, and health risk reasons influence the choice of methods of family planning for $13.6 \%$ of the respondents, while $19.7 \%$ of them specified that religion is one of the determinants of family planning methods they adopt. These responses therefore indicate that community norms influence the methods of family planning adopt by the respondents.

On the determiner's choice of family planning, $19.7 \%$ of the respondents identified themselves as the ones who decide on the choice of family planning to be adopted, while $80.3 \%$ indicate that their use of family planning is controlled by their spouse or fiancé, making it the major response. Based on the In-depth interview conducted, when asked a woman who works as a teacher, the type of family planning adopted and who determines it?

A respondent stated the type of pills used

I use coil, and I think coil is the best for me. Also, I don't decide alone, I talk to my husband and he asked me to go for the best method. So, I think coil is good for me (IDI/36yrs/Ibadan, May 2019).

Another respondent stated the methods she engaged in

I use Injection, and it is even my husband that suggests it. Without my husband I cannot use it (IDI/ 42yrs/Ibadan/May 2019). 
Reproductive Rights and Reproductive Choice of Yoruba Women in Southwestern Nigeria

In general, injection and pills are the two major family planning methods the respondents adopt but majority of them adopt these methods with the support and direction of their husband despite that they are the ones that carry pregnancy. Though, Olaitan (2011) argue that the consent of one's partner is usually sought after when choosing a birth control option. Table 3 represents the reproductive choice of women on abortion. It shows that $70.4 \%$ of the respondents can abort if situation warrants it while $29.6 \%$ of them opposed it that no situation could make them abort. Of all, the majority of the respondents gave consent that they can abort pregnancy if situations on ground warrant it.

Table 3:Abortion and Reproductive Choice

\begin{tabular}{|c|c|c|}
\hline VARIABLES & FREQUENCIES (132) & PERCENTAGES (100) \\
\hline \multicolumn{3}{|l|}{$\begin{array}{c}\text { CAN ANY SITUATION WARRANT YOU } \\
\text { TO ABORT? }\end{array}$} \\
\hline Yes & 76 & 70.4 \\
\hline No & 32 & 29.6 \\
\hline Total & 108 & 100 \\
\hline \multicolumn{3}{|l|}{$\begin{array}{l}\text { IF YOU CAN ABORT, WHAT ARE THE } \\
\text { POSSIBLE CIRCUMSTANCES }\end{array}$} \\
\hline If I need to space my children & 17 & 24.6 \\
\hline $\begin{array}{l}\text { If I had an unwanted pregnancy..... interview } \\
\text { says if he is breastfeeding and she gets pregnant }\end{array}$ & 34 & 49.3 \\
\hline $\begin{array}{l}\text { If my doctor advices........ based on my health } \\
\text { situation reacting negatively to the pregnancy }\end{array}$ & 18 & 26.1 \\
\hline $\begin{array}{l}\text { Total } \\
\text { HAVE YOU EVER ABORTED ANY } \\
\text { PREGNANCY }\end{array}$ & 69 & 100 \\
\hline Yes & 85 & 78 \\
\hline No & 24 & 22 \\
\hline Total & 109 & 100 \\
\hline \multicolumn{3}{|l|}{$\begin{array}{c}\text { IF YOU HAVE EVR ABORT, WHO } \\
\text { DETERMINED YOUR ABORTION THEN }\end{array}$} \\
\hline Myself & 31 & 32 \\
\hline My Spouse/Partner & 24 & 24.7 \\
\hline Both of us & 42 & 43.3 \\
\hline Total & 97 & 100 \\
\hline \multicolumn{3}{|l|}{$\begin{array}{l}\text { WHAT ARE THE BENEFITS OF } \\
\text { ABORTION YOU KNOW? }\end{array}$} \\
\hline It assisted in space children & 32 & 44.4 \\
\hline It makes one get more prepared for childbearing & 28 & 38.9 \\
\hline No benefit & 12 & 116.7 \\
\hline Total & 72 & 100 \\
\hline $\begin{array}{l}\text { WHAT ARE THE NEGATIVE EFFECTS } \\
\text { OF ABORTION THAT OCCUR TO YOU? }\end{array}$ & & \\
\hline It is sinful/ungodly & 43 & 32.6 \\
\hline Dizziness & 67 & 50.8 \\
\hline Nausea or Vomiting & 32 & 24.2 \\
\hline Headache & 34 & 25.8 \\
\hline Sweats & 11 & 8.3 \\
\hline Heavy bleeding & 58 & 43.9 \\
\hline $\begin{array}{l}\text { Abdominal pain or discomfort } \\
\text { Vagina smelling }\end{array}$ & 15 & 11.4 \\
\hline Fever & 53 & 40.2 \\
\hline Pregnancy signs & 24 & 18.8 \\
\hline Complications & 65 & 49.2 \\
\hline
\end{tabular}


For those that can abort based on situation, only 69 out of 76 of them responded to the circumstances that could warrant their abortion. $24.6 \%$ of the 69 respondents responded that they can only abort in order to space their children, $49.3 \%$ of them says they could abort if the pregnancy is considered unwanted, and $26.1 \%$ of these respondents say doctors' advices could make them abort. Thus, majority of these respondents came up with unwanted pregnancy as major circumstance that could make them abort.

Seeking the consent of the respondents on whether they have aborted before or not, out of 109 that responded to this question, $78 \%$ of them have aborted before while $22 \%$ have never aborted, meaning that majority of the respondents have ever aborted before.

Question on the determiners of abortion of the spouse, $32 \%$ of the respondents determined her abortion herself, aborted pregnancies of $24.7 \%$ of them were dictated or determined by their spouse or partner while $43.3 \%$ of these responses responded that their aborted pregnancy were determined by both of them.

Seeking perception of the respondents on benefit of abortion, $44.4 \%$ of them say abortion assists in spacing children, $28 \%$ of them say abortion makes one get more prepared for childbearing while $16.7 \%$ of the respondents are of the opinion that abortion has no benefit.

On the negative effects of abortion, $32.6 \%$ of the respondents responded that it is sinful and ungodly, $50.8 \%$ of them say it caused dizziness, $24.2 \%$ of the respondents see Nausea or Vomiting as negative effect, $25.8 \%$ of them see Headache as negative effect of abortion, $8.3 \%$ of them see Sweat as the negative effect of abortion, heavy bleeding is what $43.9 \%$ of the respondents see as negative effect, $11.4 \%$ of them see abdominal pain or discomfort vagina smelling as the negative effect of abortion, $40.2 \%, 18.8 \%$, and $49.2 \%$ of the respondents see fever, pregnancy signs and complications respectively as the negative effects of abortion. From all the responses, dizziness (50.8\%) and complications (49.2\%) are seen as major negative effects of abortion by the respondents.

Based on the in-depth interview conducted, a woman who works as a trader said that she can abort pregnancy when the need arises, so she was asked "On what circumstance (s)", she responded....

If I don't want pregnant and I mistakenly get pregnant, I will abort it. And again, if I am breastfeeding babies, I can abort too because it can harm the baby, I am breastfeeding (IDI/29yrs/April 2019).

Contrary to the response gave by the trader above, another woman who is also a trader said in Yoruba

"It is possible I abort pregnancy if I am seriously sick, and my health situation is reacting negatively to the pregnancy, and doctor advices me to abort it. I will abort it with my husband approval" (IDI/43yrs/May 2019)

The same woman above was asked further who determines her abortion since she said that she could abort based her husband's approval even when the doctor has advised its removal. She said:

"I can only abort based on my husband's approval because he puts it there. And again, I cannot do anything without taking permission from my husband especially when it has to do with pregnancy"

A respondent narrated on her own experience

"I'm a married woman; I do not see any reason that can prompt me aborting an innocent soul even in the name of spacing children, but if I have serious health challenge and medically it is diagnosed that my life is on danger if I don't abort it or the baby might be affected at the point of delivery, or any serious medical reason whatsoever, God will take control and I may abort it. Then, during all these medical processes, my husband must be fully carried along”"(IDI/36yrs/May 2019)

From table 4, 128 out of 132 respondents responded to the question of whether they are legally married or not. Of these $128,91.4 \%$ are legally married while $8.6 \%$ are not legally married. This indicates that majority of the respondents are legally married. On the determiner (s) of the respondents' marriage, $3.7 \%$ of the respondents decided their marriage period, parents decided the marriage period for $6.5 \%$ of them, and respondents' partners dictated the marriage period for $50 \%$ of them, while $39.8 \%$ of the respondents said they had agreement with their partners on the marriage period. Majority of these respondents revealed that their spouse determined their age at first marriage. 
Reproductive Rights and Reproductive Choice of Yoruba Women in Southwestern Nigeria

Table 4: Age at First Marriage and Reproductive Choice

\begin{tabular}{|l|c|c|}
\hline \multicolumn{1}{|c|}{ VARIABLES } & FREQUENCIES (132) & PERCENTAGES (100) \\
\hline MARRIED? & & \\
\hline Yes & 117 & 91.4 \\
\hline No & 11 & 8.6 \\
\hline Total & 128 & 100 \\
\hline WHO DETERMINED YOUR & & \\
AGE AT FIRST MARRIAGE & 4 & 3.7 \\
\hline Myself & 7 & 6.5 \\
\hline My Parents & 54 & 50 \\
\hline My Spouse & 43 & 39.8 \\
\hline Both of us & 108 & 100 \\
\hline Total & & \\
\hline IF YOU ARE SINGLE, AT & & \\
WHAT AGE WOULD YOU & 1 & 0.8 \\
LIKE TO GET MARRIED? & 74 & 32.8 \\
\hline 15-19 & 39 & 4.2 \\
20-24 & 5 & 100 \\
$24-29$ & 119 & \\
\hline 30 -above & & \\
\hline Total & & \\
\hline
\end{tabular}

Asking the respondents the age they would have loved to get married if no one is to influenced their age at first marriage, $0.8 \%$ said between ages $15-19,62.2 \%$ of the respondents would have loved to marry between the ages $20-24,32.8 \%$ of them said between $24-29$ and $4.2 \%$ of the respondents would have loved to get married 30yrs and above. These responses showed that majority of the respondents would have loved to marry between the ages 20-24yrs.

From the In-depth interview, a doctorate student at the University of Ibadan who is married was asked the person that determined her first age at marriage, she said:

"I can't say I decided my age at marriage myself because my husband must be ready for marriage before, I can also say I am ready. In short, we both determined the period of our marriage. But if I am asked when I would have loved to get married, I would say 25years, and my parents also wanted me to marry at that age, but God has His ways"

Contrary to what the respondent above said, a fashion designer who is also a university graduate said:

"I got married because I was pregnant, and my husband asked me to marry him, which I did because

I don't have choice than to accept simply because I was pregnant, and I love him"

A teacher was asked the same question, and her response is:

"It was my husband. When he told me he was ready, I had no choice than to accept it"

\section{$5 \quad$ Challenges Encountered on Reproductive Rights and Women's Choice}

The responses given from the In-depth interview conducted for the women in Sango revealed various challenges encountered on their reproductive choice. The most commonly mentioned of all the challenges on family planning, age at first marriage, abortion are namely; tradition, age, economic factors and Education. Stigmatization was also mentioned based on the fact that women seen by the members of the society having passed through the abortion process are stigmatized probably because people are not well sensitized or because it is not legalized in the country, Nigeria, or even because there are various cases of deaths as a result of abortion. 
A respondent who engages in trading activities had this to say

"The only challenge I have on the family planning I am using is that by that time I wanted to have a child, I could not get pregnant until many years. But thank God. And after when I had the baby, I told my husband to let us stop the injection and start using condom, he refused. You know our husband naw....

"No other problem than my husband. He will never want to use a condom even if at all he does not want me to be getting pregnant every time. He always wants me to have my ways. And I don't have choice than to be careful"

"I married late because I wanted to have education and have a job. My husband was ready before me, but I told him to continue saving for our marriage while I get my education." (IDI/34yrs/May 2019)

Contrary to what the previous respondent said, a fashion designer said:

"When I told my parent, I wanted to go to school more, they refused that I should get married and my husband will send me to school for the remaining education. That is the only challenge that I have. If not for my mother, I would not have married the age I got married" (IDI/40yrs/May 2019)

Challenges faced by the respondents indicate that they are faced with the challenge of stigmatization, thus, they find it uneasy to tell any of their relatives that they opt for an abortion as a means of child-spacing except their colleagues who also engage in the practice.

According to a respondent who is a lecturer,

"I do not go for an abortion to space my children at any point in time, but I am sure that those who engage in it have fear against being labeled even when you are a married woman. Abortion is unsafe in Nigeria, and seen as something very bad as it can lead to complication and can take lives" (IDI/45yrs/June 2019)

Another respondent who is a cloth seller and a mother of three said:

"When I conceived before given birth to my last born, my doctor advised me to abort the two months pregnancy because I was still breastfeeding a very small baby, and it was affecting the baby, and also the doctor said having the baby could also affect my health. When I told my mother in-law after the abortion, she didn't understand. It created a lot of misunderstanding. Thank God for my husband" (IDI/43yrs/June 2019)

\section{Discussion}

The general objective of this study is to examine the reproductive rights and women choice in Sango, Ibadan. From this objective, four other specific objectives are factored out. The first objective is to investigate on access to family planning among women in Sango Ibadan. From the quantitative and qualitative data gathered through questionnaires and In-depth interview and analyzed accordingly, it was gathered that despite the fact that women carry babies in their womb, and that they face the malady and pains caused by the pregnancy, there is a strong male dominance on reproductive choice of these women in Sango, in-spite of their level of education. Virtually all the women consulted have done one family planning or another, and some are still using family planning method as at the time of research conduct. Their husband does not cooperate with them by opting for male family planning methods such as condom, but place all the responsibilities on the women by allowing them to opt for various family planning methods such as the use of pills, injections, coils etc. Their husbands give instruction on the type of family planning methods, which indicate that these men are very meticulous about child-spacing, and the women do not have right to adopt family planning without the consent of their husbands, even though they do not have choice than to abide.

Findings show that perception of women in Sango Ibadan was not shocking because their responses on their access to abortion were matured having meant that they can abort when the need arise. Those married women who have, on one or more occasions, aborted did that partially based on doctor's professional advices but ultimately based on their husband's order. The women know where to abort, and also various methods of abortion were mentioned by them such as the use self-medication, Nurse, attending hospitals 
for professional attention, traditional medicine amongst other means. The third objective is to examine the women's decision on age at marriage in Sango, Ibadan. Unlike part of the Anambra and Northern parts of Nigeria where there is high range of early marriage among the people, high numbers of women in Sango Ibadan marry between the ages of 25 and 26years, and their marriage was influenced by their spouse on the high side, and their parent on the low side. The reason is that even when they are ready, their husbands delay their marriage because of economic reason. When the men are ready, the women have no choice than to accept the men's proposal. And very few of the women were being forced by their parents to go and marry due to age factor, economic factor, and education. Some of the women got married because they were pregnant, and they wish to abort because they were not psychologically ready, but their husbands made bear the children, thus, their husbands play a very crucial aspect on the decision of their age at first marriage.

Finally, the last which is the fourth objective is to identify challenges of reproductive decision making among women in Sango. The challenges found are pressure from the parents on their reproductive rights, cooperation from their partners, tradition of Nigerian Society, Age factor, Economic factor, Education, gender issue and Stigmatization by the members of the society.

\section{Conclusion}

The submissiveness of African women in all ramifications of life is reflecting on the high side among the women of Sango Ibadan, even on the issue of reproductive rights despite the fact that women experience direct consequences of negative result of reproduction such as the being the custodian of pregnancy. Men dictate the methods of and access to family planning for the women and refused to use male type of family planning such as condoms. Even though women's menopause is between 45 and 49 in Nigeria, according to literature, these women are aware of these before their first marriage but are still being dictated for their age at first marriage. That is, their age at first marriage is determined by their spouse because they believe economic condition of the man will determine the time and period of their wedding. Women in Sango are exposed to abortion but admitted that they can only abort prior to their husband's approval. Thus, their decision on reproduction is centred on male domination. In overall, these women in Sango Ibadan faced challenges on their reproductive decision making despite that men are responsible majorly for the approval of these choices of women. These challenges are namely; stigmatization from family and friends on abortion; education, pressure from parents, age, gender issue and tradition as factors responsible for the delay of their age at first marriage which also contribute to their early marriage; Husband's cooperation, tradition, education, and economic factors contributed to their decision on family planning.

\section{Declarations}

\subsection{Participant's Consent}

The informed consent and permissions were taken from the participants of this work.

\subsection{Competing Interests}

The author declared that there is no potential conflict of interest exist regarding this article publication.

\section{How to Cite this Article:}

Yusuff, O. (2019). Reproductive Rights and Reproductive Choice of Yoruba Women in Southwestern Nigeria. Advanced Journal of Social Science, 6(1), 138-151. doi: 10.21467/ajss.6.1.138-151

\section{References}

Aboyeji AP. 2007. Obstetrics outcome of teenage primigravidae in Ilorin. Nigeria Med. J, 33: 56-9.

Abraham, L. 2001. Redrawing the lakshmanrekha: Gender differences and cultural constructions in youth sexuality in urban India. South Asia 24:133-156.

Alison Mackinnon and Lois Bryson Beck, U. 1992. The Risk Society: Towards a New Modernity. London: Sage

Alubo O. The challenges of adolescent sexuality and reproductive health in Nigeria.Takemi Program in International Health. Boston: Harvard School of Public Health, 2000; No 166.

AniekwuNkoli I. 2003. HIV/AIDS and human rights in Nigeria: a perspective on international guidelines. J Med Biomed Res 
Ann Furedi 2007. Abortion, Choice and Reproductive Justice.London publisher.

Anna-Britt Coe. 2012. From Anti-Natalist to Ultra-Conservative: Restricting Reproductive Choice in Peru. Reproductive Health Matters.

Bankole A. 2006.Unwanted pregnancy and unsafe abortion in Nigeria: Causes and consequences. New York: Guttmacher Institute,.

Barker GK \& Rich S. 2009. Influences on Adolescent sexuality in Nigeria and Kenya: finding from recent focus group discussion. Studies in family planning, 23:199-210.

Bosveld W. 1998.Explainning between country variation in fertility: The theoretical link between individual behaviour and social context. Amsterdan, Post doctorate Onder-Zoekersopleiding Demography (Nethur-Demography Paper No.41), p. 17.

Boyd A. 2000. The world's youth 2000. Washington, DC: Population Reference. Bureau.

Bryson, L. and A. Mackinnon. 2000. Population, gender and reproductive choice: the motherhood questions. Report to Department of Family and Community Services; also published as Hawke Institute Working Paper No. 6.

C. O. Omolase, S. O. faturoti and B. O. Omolase. 2013. Awareness of family planning amongst antenatal patients in a nigerian community: an exploratory study

Center for reproductive law and policy (CRLP, 1998)

Deborah Mesce and Donna Clifton. 2011. Abortion Facts and Figures. Publisher: Population Reference Bureau

DFID. 2010. Choices for women: planned pregnancies, safe births and healthy newborns

Diaz M, Jasis MI, Steele C, Tabbutt Henry J, Widyantoro NS, Pachauiri S, Pine RN, MI, Ruminjo J. 2009. Informed choice in International Family Planning Service delivery. Strategies for the $21^{\text {st }}$ Century. New York, AVSC International, 22p.

Dixon-Muller R. 2009. Gender inequalities and reproductive health: Changing priorities in an era of social transformation and globalisation. Belgium, International Union for the Scientific Study of Population (Policy and Research Paper No.16).

Elondou-Enyegue, P.M. 2006.Integrating Teen Fertility and Gender Equity Programs. Background paper prepared for the United Nations Millennium Project.

Entwisle B, Rindfuss RR, Guilkey DK, Chamratrithirong A, Curran SR, Sawangdee Y. 2009. Community and Contraceptive Choice in rural Thailand: A case study of Nang Rong. Demography, 33(1): 1-11.

Federal Republic of Nigeria.Mid-Point Assessment of the Millenium Development Goals in Nigeria 2000- 2007. Abuja: The Office of the Senior Special Assistant to the President on the MDGs, 2008.

Goffman, E. 1959.Presentation of Self in Everyday Life. Garden City, NY: Doubleday.

Goffman, E. 1961. Asylums: Essays on the Social Situation of Mental Patients and Other Inmates. Garden City, NY: Anchor Books.

Greene, M. and T. Merrick. 2005. Poverty Reduction: Does Reproductive Health Matter. World Bank.Health, Nutrition and Population (HNP) Discussion Paper.July. Washington DC: The World Bank

Greene, M. and T. Merrick. 2005. Poverty Reduction: Does Reproductive Health Matter. World Bank.Health, Nutrition and Population (HNP) Discussion Paper.July. Washington DC: The World Bank

Greenwell KF. 1996. Contraceptives Method Mix Menu: Providing healthy choices for women. World Health Stat. Q., 49(2): 88-93.

Harrison K. Maternal mortality in Nigeria: the real issues. African journal of Reproductive Health 1997; 1(1): 7-13.

Heise L, Ellesberge M, Gottemoeller M. 1999. Ending Voilence against women. Population Reports Series No.11 Baltimore, John Hopkins School of Public Health Population Information Programme, 44p.

Iqbal Shah and Elisabeth Ahman. 2010. Unsafe Abortion in 2012: Global and Regional Levels and Trends. Reproductive Health Matters 18, no. 35 (2010).

Isiugo-Abanihe, Uche C. 2003. Male Role and Responsibility in Fertility and Reproductive Health in Nigeria. Ibadan: Centre for Population Activities and Education for Development.

Isiugo-Abanihe, Uche and Onipede, Wusu 2008. Family Structure and Reproductive Health Decision-Making among the Ogu of Southwestern Nigeria: A Qualitative Study. Ibadan: Centre for Population Activities and Education for Development.

Jaconson JL. 2000. Transforming Family Planning Programmes: Towards a framework for advancing the reproductive choice. Med. Law, 18(2-3): 255-275.

Jejebhoy SJ. 2004. The imptance of social science research in protesting adolescents' sexual and reproductive choice. Med. Law, 18(2-3): 255-275.

Judith Bruce. 2004. Reproductive Choice: The Responsibilities of Men and women. Publisher: Reproductive health matters (RHM)

Lucinda Vandervort. 2006. Reproductive Choice: Screening Policy and Access to the Means of Reproduction. Published by: The Johns Hopkins University PressStable

MaaritKohonen. 2012. The Right to Reproductive Choice: A Study in International Law by Corinne A. A. Packer. Publisher: The Johns Hopkins University Press

McDonald, P. 2000. Gender equity, social institutions and the future of fertility. Journal of Population Research 17(1):1-16.

National Assembly of Social Worker, 2012.Family planning and reproductive choice.Washington DC puplisher.

NI Aniekwu (2012). A legal perspective on reproductive health and gender-specific human rights in Nigeria. A Peer-review Journal of Biomedical Sciences June 2004, Vol. 3 No. 1 pp 21-29

Nwanunobi CO. The violation of women's rights in Nigeria: the legal dimension. A paper presented at the gender institute training workshop organized by The Social Science Academy of Niferia (SSAN) in Ijebu-Ode, 7th September 2001.

Olaitan 2011.Factors influencing the choice of family planning among couples in Southwest Nigeria. International Journal of Medicine and Medical Sciences Vol. 3(7), pp. 227-232, July 2011

Oputa C. Women and children as disempowered groups. In: Kalu A (Ed.). Women, Children and the Nigerian Law. Lagos: Federal Ministry of Justice, 1987, 1-14.

Packard. 2009. Reproductive choices of women in America. International institute for population stadies, Mumbai.

Potter JE. 1999. The Persistence of Outmoded Contraceptive regimes: The Cases of Mexico and Brazil. Popul. Dev. Rev., 25(4): 703-739.

Ramón Flecha, Jésus Gómez and LídiaPuigvert. 2001.Gramaturgy Published: Peter Lang AG

Ravindran, T.K.S and H. de Pinho (eds.). 2005. The Right Reforms? Health sector reforms and sexual and reproductive health. South Africa: Women's Health Project, School of Public Health, University of the Witwatersrand.

Royston, E. and S. Armstrong, 1989, Preventing Maternal Deaths, WHO, Geneva. 
Reproductive Rights and Reproductive Choice of Yoruba Women in Southwestern Nigeria

Singh, M.M., R. Devi and S.S. Gupta. 2009. Awareness and health seeking behavior of rural adolescent school girls on menstrual and reproductive health problems. Indian Journal of Medical Sciences 53:439-443.

Stover, J., L. Dougherty and M. Hamilton. 2005. Are cost savings incurred by offering family planning services at Emergency Plan HIV/AIDS care and treatment facilities? The Futures Group Discussion Papers.Prepared by the POLICY Project, December.

Tahzib F. Social factors in the aetiology of vesico-vagina fistulae. In: Imam A, Pittin R and Omole H (Eds.). Women and the Family in Nigeria.Darkar: CODESRIA, 2012, 75-79.

Teitelbaum, M. and J. Winter. 1998. A Question of Numbers: how Fertility and the Politics of National Identity. New York: Hill and Wang.

TitilayoCordeliaOrisaremi* and OgohAlubo(2013). Gender and the Reproductive Rights of Tarok Women in Central Nigeria

Tom Campbell, Sheila McLean. 1996. The Right to Reproduce in Human Rights: from Rhetoric to Reality 99-122.

United Nations Population Fund.Programme of Action of the International Conference on Population and Development. New York: United Nations Population Fund, 1994.

United Nations. 1968. Charter of the United Nations. 59 Stat. 1031. San Fransisco: United Nations

United Nations. 2004. ICPD Programme of Action. Report of the International Conference on Population and Development, Cairo, Egypt, 513 September 1994, UN Doc.A/CONF.171/ 13/Rev.1, UN Sales No. 95, XIII, I8, 1995.

Vasan, A., S. Dinesh and C. Prashanth. 2004. Gandhis, Choolists, All-rounders, Tarlegalu and Bad Boys: Notions of masculinity among male college students. Paper presented at the National Conference of the NIMHANS Small Grants Programme on Sexuality and Sexual Behaviour, 9-11 March 2004, Bangalore.

Wattenberg, B.J. 1997. The Population Explosion Is Over. In New York Times Magazine, 23 November.

WHO, Safe Abortion: Technical and Policy Guidance for Health Systems (2003).

WHO. 2005. Technical Consultation on Reproductive Health Indicators: Meeting Report. Geneva, 21-22 September 2005. Geneva: World Health Organization, Department of Reproductive Health and Research.

World Health Organization. 2004. Sexual and Reproductive Health Research Priorities for WHO for the Period 1998-2003. PCC (10), National reproductive health policy and strategy to achieve quality reproductive and sexual health for all Nigerians (2001)

World Health Organization. 2007. Family planning: Promoting family planning. Retrieved October 18, 2007.

Worley and Taylor/DFID. 2005. Presentation at the Reproductive Health Commodity Initiative meeting in Seattle. London: DFID.

Zoe Oxaal and Sally Baden. 1996. Challenges to women's reproductive health: maternal mortality. Institute of Development Studies, Brighton

Publish your research article in AIJR journals-

$\checkmark \quad$ Online Submission and Tracking

$\checkmark$ Peer-Reviewed

$\checkmark \quad$ Rapid decision

$\checkmark \quad$ Immediate Publication after acceptance

$\checkmark \quad$ Articles freely available online

$\checkmark \quad$ Retain full copyright of your article.

Submit your article at journals.aijr.in
Publish your books with AIJR publisher-

$\checkmark \quad$ Publish with ISBN and DOI.

$\checkmark$ Publish Thesis/Dissertation as Monograph.

$\checkmark \quad$ Publish Book Monograph.

$\checkmark \quad$ Publish Edited Volume/ Book.

$\checkmark \quad$ Publish Conference Proceedings

$\checkmark \quad$ Retain full copyright of your books.

Submit your manuscript at books.aijr.org 